\title{
PENANAMAN NILAI-NILAI RELIGIUS PADA PESRTA DIDIK DI SMA MUHAMMADIYAH O1 METRO LAMPUNG
}

\author{
Oleh. \\ Kuliyatun \\ Universitas Muhammadiyah Metro Lampung \\ e-mail: kuliyatun1971@gmail.com
}

\begin{abstract}
Abstact
This research is motivated by the findings of the negative effects of the development of globalization on the religious values in students, such as low manners, ethics. So there needs to be innovation and strategies that can reduce and overcome the problems that occur in educational institutions. Muhammadiyah 1 Metro High School has a program of planting religious values for students who adopt Islamic boarding school values. School believes that Islamic boarding school education can form a religious character. This research is included in qualitative field research. While data collection in this study uses the method of observation, interviews, and documentation. The analysis in this study uses data reduction techniques, data presentation and verification. The implementation of the planting of religious values in students uses an internalization strategy with habituation methods, advice methods, exemplary methods, and punishment methods. The results obtained from the study, namely: 1) Planting the value of worship using habituation and counselling methods, consisting of 4 activities, namely: a) prayer activities in the congregation, b) prayer together before and after learning, c) prayer dhuha, $d$ ) tausiyah. 2. Planting moral values and discipline, using habituation and exemplary methods, consisting of 3 activities, namely: a) morning greetings, b) sunnah fasts c) social services. 3. Planting trustworthy and sincere values are realized in infaq activities. 4. Planting the value of the spirit of jihad using the method of counselling. This research also found inhibiting factors in the planting of religious values, such as low awareness of children, a diverse ethnic community.
\end{abstract}

Keywords: Planting, Religious Value, Boarding School Value

\begin{abstract}
Abstrak
Penelitian ini dilatar belakangi oleh temuan-temuan pengaruh negative dari perkembangan globalisasi terhadap nilai religius pada diri peserta didik, seperti rendahnya etika. Maka perlu adanya inovasi dan strategi yang bisa mengurangi dan menangulangi permasalahan yang terjadi pada lembaga pendidikan. SMA Muhammadiyah 1 Metro menerapkan program penanaman nilai-nilai religius pada peserta didik dengan mengadopsi nilai-nilai pesantren. Sekolah meyakini pendidikan pesantren dapat membentuk karakter siswa yang religius. Penelitian ini termasuk dalam penelitian lapangan (Field Resarch) yang bersifat
\end{abstract}


kualitatif. Pengumpulan data menggunakan metode observasi, wawancara, dan dokumentasi. Analisis penelitian, menggunakan teknik reduksi data, penyajian data dan verifikasi. Adapun implementasi dalam penanaman nilai-nilai religius pada peserta didik mengunakan strategi internalisasi dengan metode pembiasaan, metode nasihat, metode keteladanan, dan metode hukuman. Hasil yang diperoleh dari penelitian, yaitu: 1) Penanaman nilai ibadah menggunakan metode pembiasaan dan nasihat, terdiri dari 4 kegiatan yaitu: a) kegiatan sholat berjama'ah, b) Do'a bersama sebelum dan sesudah pembelajaran, c) sholat dhuha, d) tausiyah. 2. Penanaman nilai akhlak dan kedisiplinan, mengunkan metode pembiasaan dan keteladanan, terdiri dari 3 kegiatan yaitu: a) salam pagi, b) puasa sunnah, c) baksos. 3. Penanaman nilai amanah dan ikhlas terealisasi dalam kegiatan infaq. 4. Penanaman nilai ruhul jihad menggunkan metode nasihat. Penelitian ini juga ditemukan factor penghambat dalam penanaman nilai-nilai religius, seperti: rendahnya kesadaran anak, lingkungan masyarakt yang beragam suku.

\section{Kata Kunci: Penanaman, Nila Religius, Nilai Pesantren}

\section{A. PENDAHULUAN}

Pendidikan merupakan suatu rekayasa sosial dalam sebuah masyarakat yang bertujuan untuk menanamkan sebuah nilai tertentu yang diinginkan. Selain itu disebutkan pula bahwa pendidikan merupakan proses dalam membentuk manusia untuk memiliki taraf kemanusiaanya (humanisasi). Penanaman nilai dalam pendidikan sangat bervariasi tergantung pada lembaga pendidikan yang merancang nilai apa saja yang ingin ditanamkan. Dikarenakan sebuah pendidikan memiliki visi dan misi sendiri yang ingin dicapai dalam diri manusia maupun lembaga pendidikan. Saat ini, dunia pendidikan dihadapi dengan arus globalisasi dan perkembangan tekhnologi yang signifikan dampaknya dapat dirasakan.

Dampak negative pada anak, seperti kurangnya etika, hal ini dapat dilihat dari beberapa peristiwa dan kasus yang cukup mengegerkan pada lembaga pendidikan ialah kasus pembunuhan seorang siswa kelas XI yang memukuli guru seninya sendiri hingga tewas, hanya persoalan sepele yaitu guru tersebut hanya menegur untuk tidak menggangu temannya di jam pelajaran berlangsung, peristiwa itu terjadi di SMAN 1 Torjun Sampang Madura, Jawa Timur. ${ }^{1}$ Ada juga kasus bullying terhadap temannya sendiri hingga depresi, kasus seorang anak berusia 10 tahun diduga melakukan kekerasan terhadap beberapa temannya karena sering menonton situs youtube yang tidak sesuai dengan umurnya. ${ }^{2}$ Dengan peristiwa yang telah terjadi tersebut, pastilah ada fator-faktor yang mempengaruhinya sampai seorang anak berani melakukan tidakan seperti

\footnotetext{
${ }^{1} \mathrm{Http}: / / \mathrm{m}$. tribunnews.com/regional/20 18/02/03/kronologi-pemukulan-guru-olehsiswa, jumat, 12-04-2018

2 https://m.detik.com/news/berita/d3845912, Jumat 12-04-2018
} 
itu dan yang melatar belakangi peristiwa tersebut.

Oleh karena itu, bertumpu pada realita yang terjadi bahwa dibutuhkan strategi-strategi yang mampu mengatasi dan mengintegrasikan kecerdasan spiritual, intelektual dan emosianal para peserta didik. Agar tujuan dari pendidikan nasional bisa tercapai dengan baik. Secara psikologi, tujuan pendidikan adalah pembentukan karakter yang terwujud dalam kesatuan esensial si subyek dengan prilaku dan sikap hidup yang dimilikinya. ${ }^{3}$ Karakter mengacu pada serangkaian sikap perilaku (behaviour), motivasi (motivation), dan keterampilan (skill) yang meliputi keinginan untuk melakukan hal baik. Tetapi karakter juga bisa diartikan sebagai kehidupan psikis seseorang yang merupakan hasil interaksi antara faktor internal dan faktor eksternal atau pengalaman yang dialaminya.

Lembaga pendidikan perlu membuat program-program yang dapat mengatasi dan menghadapi arus globalisasi yang semakin signifikan perkembangnnya. Dengan demikian, SMA Muhammadiyah 1 Metro, memiliki program bagi para peserta didiknya, bertujuan untuk membentuk insan yang berkarakter, bernilai religius dan berintelektual ilmu sains maupun agama. Program yang dibuat oleh SMA Muhammadiyah 1 Metro ialah program yang menganjurkan kepada khususnya siswa baru dan umumnya untuk seluruh peserta didik untuk tinggal diasrama supaya mendapatkan pelajaran agama

3 Alwi, Hasan dkk, Kamus Besar Bahasa Indonesia, (Jakarta: Pusat Bahasa Departemen Pendidikan Nasional dan Balai Pustaka, 2005), hlm. 1270. lebih baik dan dapat menanamkan nilai-nilai religious kepada peserta didik. SMA Muhammadiyah 1 Metro telah menerapkan sekolah berasrama (Boarding School) yang mengadopsi pendidikan pesantren. Karena sekolah sadar, dengan eksistensi pesantren yang dapat mendukung misi pendidikan nasional untuk mencerdasakan bangsa, sesuai dengan lampiran Undangundang Nomer 20 tahun 2003 tentang System Pendidikan Nasional, Peraturan Pemerintah Nomer 19 Tahun 2005 tentang Standar Proses, dan Peraturan Pemerintah Nomor 55 Tahun 2007 tentang Pendidikan Agama dan Keagamaan. ${ }^{4}$

Dengan demikian, pendidikan pesantren yang dibingkai dengan sekolah berasrama (Boarding School) dapat diterapkan di lembaga-lembaga pendidikan umum, tidak hanya diterapkan disekolah swasta yang berbasis pondok pesantren maupun sekolah yang dibawah naungan pondok pesantren atau yayasan, tetapi bisa digunakan disemua sekolah-sekolah umum yang tidak memiliki basis pesantren, sesuai dengan kebutuhan dan tujuan pendidikan yang ingin dicapai. Menurut M. Nuh (Mendiknas) dalam Republik Online yang dikutip oleh Maragustam dalam bukunya, Filasafat Pendidikan Islam Menuju Pembentukan Karakter, tradisi (pembiasaan) dipesantren sangat penting di sekolah. ${ }^{5}$ Dengan demikian,

4 Abd, Halim Soebahar, Kebijakan Pendidikan Islam dari Ordonansi Guru sampai UU Sisdiknas, (Jakarta: PT RajaGrafindo Persada, 2013), hlm. 42.

5 Maragustam, Filsafat Pendidikan Islam Menuju Pembentukan Karakter, (Yogyakarta: Pascasarjana FITK UIN Sunan Kalijaga, 2018), hlm. 287. 
pendidikan dan nilai-nilai pesantren memang sangat dibutuhkan dalam pendidikan saat ini, karena proses pendidikan tidak hanya transfer knowledge saja tetapi juga penanaman nilai-nilai religious dalm pembentuk karakter pada peseta didik. Karena melihat eksistensi pesantren dalam membentuk karakter, akhlak peserta didik dan mendapatkan apresiasi terhadap lembaga-lembaga pendidikan yang bukan berbasis pesantren.

Berdasarkan permasalahan tersebut, perlu adanya inovasi terbaru yang mampu mengatasi permasalahanpermasalahan yang berkaitan dengan rendahnya tingkat religiusitas peserta didik. Salah satunya dengan cara menanamkan nilai religus pada peserta didik di SMA Muhammadiyah 1 Metro. Dalam penanaman nilai-nilai religius di SMA Muhammadiyah 1 Metro ini sebagian besar mengadopsi dari pendidikan pesantren. Tujuannya agar siswa mampu memiliki nilai karakter yang kuat sesuai dengan visi dan misi SMA Muhammadiyah 1 Metro.

SMA Muhammadiyah 1 Metro sendiri telah menerapkan penanaman nilai religius pada peserta didik dengan system boarding school yang mengadopsi pendidikan pesantren sejak empat tahun yang lalu, tepatnya pada tahun 2015. SMA Muhammadiya 1 Metro mengadopsi pendidikan pesantren ini, bukan untuk merubah sekolah menjadi pesantren, tetapi sekolah hanya mengadopsi pendidikan pesantren yang diyakininya dapat menanamakn nilai-nilai religius dan membentuk karakter yang berintelektual dan religius. SMA
Muhammdiyah 1 Metro sendiri adalah sekolah SMA yang pertama kali memprogramkan penanaman nilai-nilai religius dengan mendirikan boarding school yang diadopsi dari pendidikan pesantren. Tetapi tidak bisa dipungkiri, dalam penerapan program nilai pesantren ini, sekolah tidak langsung sukses dan berhasil, tetapi banyak masalah atau kendala yang dihadapinya sampai saat ini. Kendala yang selalu menghambat berjalannya program ini ialah Karena kultur didaerah sekitar beragam dan lingkungan masyarakat dan pergaulan, karena SMA Muhammadiyah 1 Metro berletak diperkotaan.

Untuk membatasi penelitian ini, peneliti berfokus pada bagaimana implementasi penanaman nilia-nilai religius yang mengadopsi pendidikan pesantren di SMA Muhammadiyah 1 Metro?, serta bagaimana hasil dari proses implementasi penanaman tersebut bagi peserta didik?

\section{B. METODE PENELITIAN}

Dalam penelitian ini, untuk memperoleh data yang dibutuhkan akan menggunakan beberapa metode penelitian sebagai berikut:

\section{Jenis Penelitian}

Jenis penelitian yang digunakan adalah penelitian kualitatif, yaitu penelitian yang dilakukan pada kondisi yang alamiah. ${ }^{6}$ Sedangkan Pendekatan yang digunakan dalam penelitian ini adalah pendekatan psikologi. Psikologi atau ilmu jiwa adalah ilmu yang mempelajari jiwa dan prilaku

6 Sugiyono, Metode Penelitian Pendidikan, Pendekatan Kuantitatif, Kualitatif dan $R \& D$, (Bandung: Alfabeta, 2011), hlm. 14 
seseorang melalui gejala yang dapat diamatinya. Lokasi penelitian ini dilakukan di SMA Muhammadiyah 1 Metro Lampung beralamatkan di jalan Khiarbras No. 65 Ganajarsari, Metro Barat, Kota Metro provinsi Lampung.

\section{Sumber Data}

Sumber data dalam penelitian ini adalah semua data, kegiatan, ataupun informasi yang dapat dijadikan sebagai sumber rujukan dalam penelitian ini. Namun yang diutamakan adalah data yang berupa informasi dari informan yang terbentuk kata-kata dan kejadian lapangan secara realita. Subjek yang dijadikan sebagai sumber data dalam penelitian ini diantaranya, ialah: a. Kepala asrama, b. Kepala sekolah, b. Guru (Ustadz), c. Peserta didik.

\section{Metode Pengumpulan Data}

Metode pengumpulan data yang akan digunakan dalam penelitian ini adalah sebagai berikut: a. Metode observasi dilakukan untuk memperoleh informasi tentang kelakuan manusia seperti terjadi dalam kenyataan, ${ }^{7}$ b. Metode wawancara digunakan untuk mencari dan menggali data penelitian $\mathrm{c}$. Metode Dokumentasi merupakan teknik mencari data mengenai hal-hal atau variable yang berupa catatan, traskip, buku, surat kabar, majalah, prasasti, notulen rapat, lengger, agenda, dan sebagainya. ${ }^{8}$

\section{Uji Keabsahan}

Dalam penelitian ini, menggunakan teknik untuk menguji keabsahan data, yaitu Triangulasi, yaitu

7 S. Nasution, Metode Research, (Peneltian Ilmiah), (Jakarta: Bumi Aksara, Cetak ke-1, 1996), hlm.106.

8 Suharsimi Arikunto, Prosedur Penelitian Suatu Pendekatan Praktik, (Jakarta: PT. Rineka Cipta, 2013), hlm. 274. teknik pengecekan data dari berbagai sumber dengan berbagai waktu. Dalam penelitian ini peneliti menggunakan trangulasi sumber dan trangulasi teknik. $^{9}$

\section{Teknik Analisis Data}

Analisis data yang digunakan adalah teknik analisis data model Miles dan Huberman yaitu dalam penelitian analisi data dilakukan terus menerus sampai akhir penelitian. ${ }^{10}$ Kemudian dianalisis melalui tiga kompenen yang meliputi reduksi data, penyajian data, dan pengambilan kesimpulan (verifikasi). ${ }^{11}$

\section{KAJIAN TEORI DAN PEMBAHASAN \\ 1. Penanaman Niali-nilai Religius}

Penanaman secara etimologis berasal dari kata "tanam" yang berarti menabur benih, yang semakin jelas jika mendapatkan awalan dan akhirat menjadi "penanaman" yang berarti proses, cara, perbuatan menanam, menanami atau menanamkan. ${ }^{12}$ Sedangkan nilai adalah prinsip atau hakikatnya yang menentukan harga atau nilai dan makna bagi sesuatu. Nilai adalah suatu perangkat keyakinan atau perasaan yang diyakini sebagai suatu identitas yang memberikan corak

\footnotetext{
Sugiyono, Metode Penelitian Pendidikan, Pendekatan Kuantitatif, Kualitatif dan $R \& D$..., hlm. 372.

${ }^{10}$ Ibid..., hlm. 337.

11 Uhar Suharsaputra, Metode Penelitian Kualitatif, Kuantitatif dan Tindakan, (Bandung: PT. Refika Aditama, 2012), hlm. 216.

12 Pusat Bahasa Departemen Pendidikan Nasional, Kamus Besar Bahasa Indonesia, (Jakarta: Balai Pustaka, 2003), hlm. 1134. 
yang khusus kepada pola pemikiran, perasaan, keterikatan maupun prilaku. ${ }^{13}$

\section{a. Pengertian Religius}

Religius adalah nilai kerohanian yang tertinggi, sifatnya mutlak dan abadi, serta bersumber pada kepercayaan dan keyakinan manusia. Religius merupakan kata sifat dari religious (inggris) "connected with religion or with particular religion". Glock dan Stark menyatakan bahwa, Religius sebagai keyakinan yang berhubungan dengan agama, yang dapat dilihat melalui aktivitas atau perilaku individu yang bersangkutan dengan agama dan keyakinan yang di anut. Religius bukanlah merupakan sesuatu yang tunggal tetapi merupakan system yang terdiri dari beberapa aspek. Didalam psikologi agama dikenal dengan religius consciousness (kesadaran beragama) dan religius experiences (pengalaman beragama). Glock dan Stark membagi religiuitas menjadi lima dimensi, yaitu religious belief, religious practice, religious felling, religions knowledge dan religious effect. ${ }^{14}$

Religius atau sikap keagamaan dapat diartikan sebagai suatu proses terhadap daya ruhaniyah yang menjadi motor penggerak mengarahkan tingkah laku manusia dalam kehidupan seharihari terdiri dari perasaan, fikiran, angan-angan untuk melaksanakan kepercayaan kepada tuhan dengan anjuran dan kewajiban yang

13 Abu Ahmad dan Noor Salim, Dasar-Dasar Pendidikan Agama Islam, (Jakarta: Bumi Aksara, 2008), hlm. 202.

${ }^{14}$ Charles Y. Glock and Rodney Stark, Religion and Society in Tension, (Chicago: Rand McNally and Company, 1965). berhubungan dengan agamanya. ${ }^{15}$ Religius adalah menjalankan ajaran agama secara menyeluruh dan hal yang paling mendasar ialah menjadikan sebagai landasan pendidikan. ${ }^{16}$

\section{b. Nilai Religius \\ yang}

\section{Ditanamkan}

Menurut Fathurrahman nilai-nilai religious terbagi menjadi 5, sebagai berikut: ${ }^{17}$

1) Nilai Ibadah

Secara istilah berarti khidmat kepada Tuhan, taat mengerjakan perintah-Nya dan menjauhi laranganNya. Ibadah adalah ketaatan manusia kepada tuhan yang diimplementasikan dalam kegiatan sehari-hari misalnya, sholat, puasa, zakat dan lain sebagainya. $^{18}$ Ibadah baik umum maupun khusus merupakan konsekuensi dan implikasi dari keimanan terhadap Allah SWT yang tercantum dalam dua kalimat syahadat."asyhadu alla ilaaha illallaah, waasyhadu anna Muhammadar Rasulullah. Bahwa ibadah adalah ketaatan manusia kepada Tuhan yang diimplementasikan dalam kegiatan sehari-hari

\section{2) Nilai Ruhul Jihad}

Ruhul jihad adalah jiwa yang mendorong manusia untuk bekerja atau berjuang dengan sungguh-sungguh.

${ }^{15}$ Imam Bawai, Pengantar Ilmu Jiwa Perkembangan, (Surabaya: PT. Bina Ilmu, 1985), hlm. 19.

${ }^{16}$ Asmaun Sahlan, Mewujudkan Budaya Religius di Sekolah, (Malang: UIN Maliki Pres, 2009), hlm. 27

17 Faturrohman, Budaya Religius Dalam Peningkatan Mutu Pendidikan, Tinjauan Teoritik dan Praktik Konstekstualisasi Pendidikan Agama Di Sekolah, (Yogyakarta: Kalimemedia, 2015), hlm. 60-69. 
Hal ini didasari adanya tujuan hidup manusia, yaitu Hablumminallah, Hamblumminnas dan Hamblum min alalam. Dengan adanya komitmen ruhul jihad maka aktualisasi diri dan melakukan perkerjaan selalu didasari sikap berjuang dan ikhtiar dengan sungguh-sungguh. ${ }^{19}$ Mencari ilmu merupakan salah satu manifestasi dari sifat Jihadunnafsi yaitu memerangi kebodohan dan kemalasan.

3) Nilai Akhlak dan Disiplin

Akhlak merupakan bentuk jama' dari khuluq, artinya perangai, tabiat, rasa malu dan adat kebiasaan. Sedangkan kedisiplinan itu termanifestasi dalam kebiasaan dalam kebiasaan manusia ketika melaksanakan ibadah rutin setiap hari. Apabila manusia melaksanakan ibadahnya dengan tepat waktu, maka secara otomatis nilai kedisiplinan telah tertanam pada diri orang tersebut. ${ }^{20}$

4) Nilai Keteladanan

Nilai keteladanan tercermin dari perilaku guru, keteladanan merupakan hal yang sangat penting dalam pendidikan dan pembelajaran.

\section{5) Nilai Amanah dan Ikhlas}

Secara etimologi amanah artinya dapat dipercaya dan tanggung jawab. Dalam konteks pendidikan, nilai amanah harus dipegang oleh seluruh pengelola lembaga pendidikan. Sedangkan ikhlas diartikan bersih atau hilangnya rasa pamrih atas segala sesuatu yang diperbuatnya. ${ }^{21}$

\footnotetext{
19 Faturrohman, Budaya Religius Dalam Peningkatan Mutu..., hlm. 62.

${ }^{20} \mathrm{Ibid}, . . .$, hlm. 63.

${ }^{21}$ Ibid, ..., hlm. 60-69.
}

\section{Strategi Penanaman Nilai-nilai Religius}

a. Pengertian Strategi

Strategi adalah suatu pola yang direncanakan dan ditetapkan secara sengaja untuk melakukan kegiatan atau tindakan. $^{22}$ Menurut J.R David dalam pendidikan strategi diartikan sebagai perencanaan yang berisi tentang rangkaian kegiatan yang didesain untuk mencapai tujuan pendidikan tertentu. ${ }^{23}$

Strategi pendidikan pada dasarnya masih bersifat konseptual tentang keputusan yang akan diambil dalam suatu pembelajaran. Oleh karena itu, untuk mengimplementasikannya strategi tersebut disesuaikan dengan metode pembelajaran tertentu sebagai cara kerja yang bersistem untuk memudahkan pelaksanaan kegiatan penanaman nilai religius guna untuk mencapai tujuan yang telah direncanaka.

b. Strategi dan Metode Pembentukan Nilai Religius

Strategi yang akan di teterapkan sesuai dengan kebutuhan dan kapasitasnya. Startegi yang akan digunakan dalam penenaman nilai-nilai religious pada peserta didik, yaitu Startegi internalisasi adalah penghayatan terhadap suatu doktrin atau nilai, sehingga merupakan keyakinan dan kesadaran akan kebenaran doktrin atau nilai yang diwujudkan dalam sikap dan prilaku. ${ }^{24}$

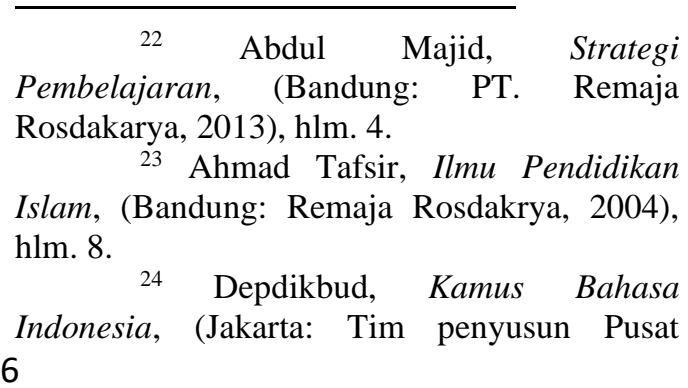
186 
Maragustam berpendapat, bahwa jika karakter merupakan 100\% keturunan atau bawaan sejak lahir, maka karakter tidak bisa terbentuk. Namun, jika bawaan (heriditas) hanyalah salah satu factor pembentuk karaker, maka bisa dibentuk semenjak dini. Dengan diajarkan secara sistematis dalam model pendidikan karaker holistic integrative (pendidikan formal, informal, dan non formal). ${ }^{25}$ Ada lima rukun pembentukan karakter, yaitu: ${ }^{26}$ 1) Moral Acting (tindakan yang baik) dengan cara habituasi (pembiasaan) dan pembudayaan, 2) Membelajarkan pengetahuan tentang nilai-nilai yang baik (moral knowing), 3) Moral feeling dan loving (merasakan dan mencintai yang baik), 4) Moral loving berawal dari mindset (pola pikir), 4) Keteladanan (moral modelling) dari lingkungan sekitar, 5) Pertaubatan dari segala dosa dan halhal yang tidak bermanfaat sekalipun.

\section{Hasil Penanaman Nilai-nilai Religius di SMA Muhammadiyah 01 Metro, Lampung.}

a. Implementasi Penanaman Nilai-nilai Religius Kepada Peserta Didik

SMA Muhammadiyah 01 Metro merupakan sekolah pertama di kota Metro yang mendirikan system sekolah berasrma (Boarding School) sejak tahun 2015, dengan mengadopsi pendidikan pesantren dalam proses

Pembinaan dan Pengembangan Bahasa, 2002), hlm.439

${ }^{25}$ Maragustam, Filsafat Pendidikan Islam, Menuju Pembentukan Karakter, (Yogyakarata: Pascasarjana Fakultas Ilmu Tarbiyah dan Keguruan, Universitas UIN Sunan Kalijaga, 2018), hlm. 285-291.

${ }^{26}$ Ibid..., hlm. 285-289. penamanan nilai-nilai religius guna dapat membentuk karakter yang religius dan berintelektual. Boarding school adalah sekolah berasrma yang tidak hanya memberikan ilmu (transfer knowledge) terhadap peserta didik, tetapi juga membina dan mendidik peserta didik dalam berbagai aspek kehidupannya yang akan datang.

Berdasarkan Hasil obeservasi yang telah dilakukan kegiatan keagamaan dalam penanaman nilainilai religious yang terdapat di SMA Muhammadiyah 1 Metro sebagian besar mengadopsi nilai-nilai pesanter, seperti peserta didik masuk sekolah pukul 07:00 setiap pagi selalu tadarus Qur'an dan menyetorkan hafalan kepada guru yang bertugas, sebelum jam istirahat peserta didik diberi waktu 15 menit untuk melakukan sholat dhuha, peserta didik diwajibkan sholat berjama'ah di masjid dan mendengarkan tausyiah ba'da dzuhur. Berdasarkan hasil penilitian dapat disimpulkan, bahwa SMA Muhammadiyah 1 Metro memiliki keinginan untuk membentuk peserta didik yang berkarater religius, berintelektual, disiplin ilmu, tanggung jawab dan mandiri. Hal ini merupakan sebagai gambaran bahwa SMA Muhammmadiyah 1 Metro benar-benar mendidik dan menanamkan nilai-nilai religious pada seluruh penghuni sekolah tersebut, baik itu peserta didik, karyawan maupun guru yang berada dalam lingkungan sekolah. Peserta didik yang ada di SMA Muhammadiyah 1 Metro keseluruhan beragama Islam, oleh karena itu, maksud dari program penanaman nilai religious yang ditanamkan pada diri 
peserta didik guna dapat menjadi landasan keagamaan bagi para peserta didik untuk tidak mudah terpengaruh dengan budaya barat atau perkembangan zaman dan bisa mengambil keputusan dengan bijaksana sesuai dengan ajaran agamanya.

Satuan pendidikan sebenarnya selama ini sudah mengembangkan dan melaksnakan nilai-nilai religious dalam pembentukan karakter, melalui program operasional satuan pendidikan masing-masing. Hal ini merupakan prakondisi pendidikan karakter pada satuan pendidikan yang untuk selanjutnya telah dijelakan atau dirinci dalam kajian kurikulum 2013 yang mengarah dalam pembentukan karakter. Nilai karakter yang dijelaskan dalam kurikulum 2013 seperti, keagamaan, gotong royong, kebersihan, kedisiplinan, kebersamaan, toleransi, peduli terhadap sekitar, kerja keras dan sebagainya.

SMA Muhammadiyah 1 Metro dalam mengimplementasikan penanaman nilai-nilai religius pada perta didik sebagaian besar mengadopsi pendidikan pesantren, karena bila diamati pendidikan pesantren dalam membentuk karakter santri dan menanaman nilai-nilai religius bisa berjalan dengan baik dan menghasilkan output-output yang berkulitas, secara intelektualnya maupun religiusitasnya. Oleh sebab itu, sekolah melihat dan tidak meragukan untuk mengadopsi pola pendidikan pesantren dalam penanaman nilai religius pada diri peserta didik. Pendidikan pesantren diyakini dapat membantu dan mempermudah proses penanamn nilai religius pada diri peserta didik. Kegiatan pesantren yang diadopsi oleh sekolah SMA Muhammadiayah 1 Metro, seperti Tadarus Al-Qur'an, sholat dhuha, sholat berjam'ah, mengkaji kitab Hadist dan kegiatan tausyiah.

Berdasarkan hasil wawancara bersama bapak Rudion ${ }^{27}$, selaku guru al Islam, penanaman nilai religius pada peserta didik melalui kegiatan Tadarus Qur'an, menunjukan bahwa guru AlIslam berupaya menanamkan nilai religius melalui kegiatan Tadarus Qur'an. Hal ini bisa terlihat ketika guru Al-Islam memberikan arahan langsung tentang pentingnya menjaga sopan santun ketika kegiatan Tadarus Qur'an berlangsung.

Nilai kegiatan keagamaan Tadarus Qur'an adalah salah satu dalam penamanan nilai-nilai religius yang diberikan pada peserta didik. Dalam pelaksanaan kegiatan ini, seluruh guru atau warga sekolah juga memberikan contoh secara langsung kepada peserta didik dengan menjaga sikap ketika kegiatan tadarus Qur'an sedang berlangsung. Para guru berusaha untuk menanamkan nilai akhlak melalui kegiatan Tadarus Qur'an. Penanaman nilai-nilai religious pada diri peserta didik ini dilakukan dalam setiap hari. Proses penanaman nilai-nilai religious di SMA Muhammadiyah 1 Metro ini mengunakan beberapa metode yang dianggap efektif oleh pihak sekolah dan asrama. Metode yang digunakan dalam proses implementasi penanaman

27 Wawancara dengan Rudion, selaku Waka Al-Islam Di SMA Muhammadiyah 1 Metro, 06 Maret 2019, pukul 10:00 
nilia-nilai religius adalah mengunakan metode pembiasaan, metode nasihat, metode keteladanan dan metode hukuman. Semua metode tersebut digunakan untuk membentuk peserta didik agar dapat memiliki karkater yang religious sesuai dengan tujuan SMA Muhammadiyah 1 Metro yang tertuang dalam visi yaitu terdidik berdasarkan aqidah Islam, cerdas dan unggul dalam ilmu pengetahuan dan teknologi serta berbudaya lingkungan.

Metode nasihat dalam menanamkan nilai-nilai religious diaplikasikan dengan secara intensif dan berkelanjutan. Metode ini digunakan ketika dilaksanakan kegiatan kajian, mengaji yang terjadwal rutin maupun dalam keadaankeadaan tertentu yang tidak terjadwal. Kegiatan kajian yang menggunakan metode nasihat ini berupa kajian ba'da magrib yaitu tausiyah, kajian Riyadush Shalihin $^{28}$, HPT (Himpunan Putusan Tarjih) ${ }^{29}$, dan pembinaan angkatan yang terjadwal. ${ }^{30}$

Nasihat yang diberikan merupakan nilai-nilai agama sebagai dasar pemahaman agar terbentuknya karakter religious peserta didik. Dalam keseharian nasihat ini selalu diberikan

28 Riyadush Shalihin merupakan sebuah buku dari kumpulan hadits-hadits pilihan yang ditulis oleh Imam Nawawi yang digunakan sebagai materi yang dibahas dalam kajian rutin diasram

29 HPT (Himpunan Putusan Tarjih) merupakan sebuah buku, produk intelektual tertinggi dari Majelis Tarjih yang digodok secara intensif dalam Musyawarah Nasional Tarjih

30 Pembinaan angkatan merupakan kegiatan rutin yang dilakukan. Pembinaan angkatan ini dilakukan sehari dalam 2 minggu yang bertempatan pada hari minggu, pembinaan ini dilakukan pada penghuni asrama. dengan cara yang dogmatis yaitu memaparkan pandangan agama terhadap nilai tertentu. Hal ini dibuktikan dengan materi kajian yang dilakukan. Dengan demikin, maka nasihat yang diberikan merupakan nasihat yang didasari dari hadits-hadits yang ada, sehingga terlihat bahwa nasihat yang diberikan merupakan nasihat dogmatis. Dalam Penanaman nilai-nilai religious pada peserta didik tidak hanya mengunakan nasihat saja, melainkan ada beberpa metode yang digunkan di SMA Muhammadiyah 1 Metro. Hal ini dimakasudkan agar nilai-nilai religious tertanam dengan optimal. Metode yang digunankan selain nasihat adalah metode pembiasaan. Dalam hal ini pembiasaan dilakukan sesuai dengan nilai-nilai religious dalam penanaman nilai-nilai religious pada peserta didik.

Menurut Nurcholis Madjid, suasana religius yang berbentuk ritual dan simbolik dianggap sebagai "bingkai" atau "kerangka", sebab itu ritus (kegiatan keagamaan) dan formalitas bukanlah tujuan, ia akan baru memiliki makna yang hakiki jika menghantarkan orang yang bersangkutan kepada tujuannya yang hakiki, yaitu kedekatan (taqarrub) kepada Allah dan kebaikan kepada sesama manusia (akhlak karimah). ${ }^{31}$

Kegiatan demi kegiatan yang dilaksanakan disekolah SMA Muhammadiyah 1 Metro, semuanya mengarahkan agar siswa dapat merasakan dan terbiasa melakukan sesutu yang baik dan bermanfaat.

31 Nurcholis Majid, Masyarakat Religius, (Jakarta: Paramedina, 1997), hlm. 128. 
Seperti kegiatan bakti social yang dilakukan diberbagai tempat, seperti panti asuhan, dijalana dan lain sebagainya. Kegiatan ini membiasakan peserta didik untuk selalu membantu dan menghargai kehidupan orang lain tanpa mengharapkan sesuatu (pamrih). Pembiasaan mengabdi pada Alllah SWT sebagai Tuhan Pencipta telah dilakukan dan menjadi sebuah kewajiban yang harus dilakukan setiap orang muslim. Hal ini diwujudkan supaya para peserta didik di SMA Muhammadiyah 1 Metro dapat menjadikan dirinya sebagai hamba Allah SWT.

Seperti halnya nilai amanah dan tanggung jawab juga dibiasakan dalam setiap aktivitas yang dilaksanakan. Hal ini berkenaan dengan, dijadikannya peserta didik menjadi pengurus dalam organisasi maupun dalam setiap acara atau event. Keduanya merupakan amanah yang diberikan oleh SMA Muhammadiyah 1 Metro kepada para peserta didik untuk senantiasa dilaksanakannya dengan penuh rasa tanggung jawab atas apa yang telah diamanahkan. Dalam melaksanakan amanah ini harus diikut dengan tanggung jawab terhadap amanah yang telah diberikan. Sehingga amanah dan tanggung jawab dibiasakan dilingkungan sekolah melalui tugas yang diberikan. Ini semua dibuktikan dengan wajibkannya para peserta didiknya untuk melaksanakan tahfidz Qur'an dan melakukan sholat berjama'ah, selain itu sekolah membuat kegiatan yang dilaksanakan setiap tahunnya untuk membiasakan para peserta didik beramal kepada sesama, kegiatan ini biasa disebut dengan Baksos (Bakti Sosial).

Metode selanjutnya yang digunkan dalam penanaman Nilai-nilai religious pada peserta didik ialah dengan memberikan keteladanan. Keteladanan ini diberikan oleh para guru SMA Muhammadiyah 1 Metro. Hasil wawancara bersama bapak Sriyanto, bahwa mengindikasikan bahwa keteladanan telah diberikan sebagai metode dalam menanamkan nilai-nilai religious yang diinginkan. Selain itu dalam kajian atau kultum yang dilakukan oleh para guru selalu dianjurkan agar guru dapat selalu memberikan contoh dan menjadil modelling yang baik bagi para peserta didiknya. Seperti yang dikatakan oleh Feri Irawan setelah usai kultum, yang diberikan bahwa guru harus menjadi contoh pada para peserta didiknya.

Hukum (punishment) menjadi metode selanjutnya yang digunakan sekolah SMA Muhammadiyah 1 Metro dalam penanaman nilai-nilai religious. Pada dasarnya aturan yang ada semuanya diciptakan agar seluruh peserta didik terbiasa dengan nilai-nilai religious yang ada, sehingga proses pembentukan karkater pun dapat tercapai dengan baik. Berdasarkan keterangan bapak Rudion, ketika diberikan pertanyaan tentang menggunakan metode hukuman terhadap pembinaan, bahwa diharapkan peserta didik yang melanggar akan diberi hukuman, supaya sadar dan paham atas kesalahan yang dilakukannya.

Berkaitan dengan hukuman yang diberikan merupakan salah satu langkah dan upaya dalam membentuk 
peserta didik menjadi peserta didik yang bernilai religious. Dalam praktiknya hukuman yang diberikan juga mengedepankan pembiasaan dalam mengamalkan nilai-nilai religious. Berdasarkan hasil observasi dan wawancara terhadap para warga sekolah dapat ditarik kesimpulan bahwa implementasi penanaman nilainilai religius siswa di SMA Muhammadiyah 1 Metro bisa dilihat dari siswa terbiasa berbuat baik, melakukan kegiatan baksos, aktif organisasi keislaman, dan taat peraturan yang memberikan pembelajaran agama dan bisa mengetahui kompetensi yang dimiliki siswa, siswa menjadi lebih kuat taqwanya, kuat aqidahnya, mengetahui nilai-nilai religius yang lain seperti punya wawasan ma'rifat dan mempunyai adap kepada guru, teman, kedua orangtua.

\section{Hasil Penanaman Nilai-Nilai Religius Pada Peserta Didik Di SMA Muhammadiyah 01 Metro}

Berdasarkan hasil penelitian yang dilakukan dalam penanaman nilai-nilai religious pada peserta didik di SMA Muhammadiyah 1 Metro, mencakup kegiatan-kegiatan keagamaan yang sudah diprogram oleh guru Pendidikan Agama Islam, kepala sekolah, wakil kepala sekolah dan pembina asrama. Penanaman nilai nilai religious di SMA Muhammadiyah 1 Metro diwujudkan dalam berbagai kegiatan keagamaan. Berdasarkan hasil observasi yang telah dilakukan, dalam melaksanakan penanaman nilai-nilai religius pada peserta didik SMA Muhammaduyah 1
Metro terindikasi mengunakan atau mengadopsi pola pendidikan pesanteran, guna untuk menunjang dan membantu proses pembentukan karakter religius.

Berdasarkan hasil observasi yang telah lakukan, kegiatan keagamaan yang diadopsi dari pendidikan pesantren yang diterapkan di SMA Muhammadiyah 1 metro ini sesuai dengan teori Muhammad Fathurrohman, antara lain tadarus alQur'an, sholat dhuha, sholat berjama'ah, puasa sunnah, peringatan hari besar Islam, dan doa bersama (istighosah). Disamping itu, kegiatan lain juga ada seperti dibiasakan mendengarkan murotal, infaq dan selalu peduli dengan sekitar.

Berdasarkan dari hasil penelitian, tentang penanaman nilai-nilai religius pada peserta didik yang mengadopsi nilai pesantren, dapat dikatakan berhasil, terlihat dari peserta didik yang menunjukan sikap positif seperti beribadah secara rutin dari mulai kegiatan 3S (senyum, sapa dan salam) tadarus al-Qur'an, berdoa di awal dan diakhir pelajaran, sholat dhuha, puasa sunnah, sholat berjama'ah, sholat jum'at, infaq dan peringatan hari besar Islam, dan istighosah. Peserta didik menunjukan sikap ramah ketika bertemu dengan oranng lain. Hal ini terbukti ketika peneliti datang pertama kalinya disambut dengan ramah dan berjabat tangan meskipun belum saling kenal. Menurut ibu resesi guru bimbinang konseling (BK), mengatakan perilaku para siswa sudah terarah dan terjadi perubahan, seperti sikap/etika yang baik. Pendidikan pesantren yang dilakukan disekolah 
memberikan dampak yang positif bagi siswa maupun warga sekolah.

Berdasarkan hasil observasi yang dilakukan, setelah diterapkannya nilainilai dan budaya pesantren disekolah, para peserta didik lebih mengerti tentang kewajibannya sebagai seorang muslim, seperti ibadah lebih terjaga, sopan dan patuh terhadap guru. Maka emosional peserta didik dapat terjaga dan kedekatan lahir batin dalam pembelajaran berjalan dengan baik dan sesuai yang diharapkan.

a. Nilai-nilai Religius yang ditanamkan pada peserta didik

Dalam nilai-nilai yang ditanamkan merupakan religiusitas dimana suatu hal yang multidimensi yang meliputi kognitif, emosi, perilaku dan interpersonal. ${ }^{32}$ Sehingga religiusitas dibagi menjadi lima aspek yaitu ideological, intellectual, public practice, private practice dan religious experience. Nilai-nilai religius yang diberikan kepada peserta didik adalah sebagai berikut:

1) Nilai Ibadah

Nilai ibadah yang ditunjukan oleh peserta didik dapat dilihat dari kegiatan sehari-hari seperti sholat dhuha, sholat berjama'ah, sholat jum'at, tadarus al-Qur'an dan lainlainnya. Dengan menunjukan karakter religious terutama nilai ibadah ini, dapat terlihat bahwa nilai-nilai dan budaya pesantren yang digunakan sebagai penanaman nilai-nilai religious pada peserta didik sudah berhasil

32 Doanea, M. J. The Associantion Between Religiosty and Subjective Well-Being: The Unique contribution of religious service attendance and the mediating role of perceived religious social support. The iris Jourbal of Psyhology, 43 (1), 2013, hlm. 49-66. dengan baik. Hal ini, dapat diketahui melalui absensi sholat yang terlampir. Selain itu juga, dibuktikan dengan hasil observasi peneliti ketika waktunya istirahat tiba, peserta didik dengan kesadarannya sendiri menuju kemesjid untuk melaksanakan ibadah sholat sunnah (sholat dhuha).

Berdasarkan hasil wawancara bersama bapak Fikri, bapak Ridwan dan Puji Lestari (siswi) ${ }^{33}$ dan observasi yang telah dilakukan, bahwasannya nilai-nilai ibadah sudah terlaksana dengan baik sesuai dengan tujuan dan harapan sekolah dalam menanamkan nilai-nilai religious melalui pembiasaan melakukan sholat dhuha, sholat berjama'ah, infaq dan lainnya. Berjalan dengan baik tanpa adanya paksaan dan dilakukan dengan kemauan sendiri tanpa adanya embel-embel (reward) dan juga tidak perlu dioprak-oprak dari bapak ataupun ibu guru. Selain disekolah, praktik ibada juga dilakukan, karena merak sudah mulai sadar atas kewajibanya sebagai seorang muslim.

Penanaman nilai ibadah selanjutnya yaitu, membiasakan membacaan do'a setiap pagi yang dipandu oleh guru yang bertugas. Kegiatan ini dilakukan untuk mendapatkan ridho Allah SWT, agar apa yang dikerjakannya bernilai ibadah. Berdasarkan hasil wawancara

33 Wawancara Dengan Bapak Fikri, Selaku Wakil Kepala Sekolah SMA Muahmmadiyah 1 Metro di Bidang Sarpra, 3001-2019, Pukul 09.00 WIB, Wawancara Dengan Bapak Ridawan Awalludin, S.E, Selaku Guru Kewarganegaraan di SMA Muhammadiyah 1 Metro, 05-02-05, Pukul 09.30, Wawancara Dengan Puji Lestari, peserta didik SMA Muhammadiyah 1 Metro Kelas XI IPB, 05-02-19, Pukul 12.30 WIB. 
bersama bapak Fikri, mengatakan bahwa, membiasakan membaca doa sebelum melakukan kegiatan belajar ini dengan harapan agar apa yang kita terima selama kegiatan pembelajaran bermanfaat dan bernilai ibadah.

2) Nilai Akhlak dan Kedisiplinan Nilai akhlak yang disampaikan oleh peserta didik SMA Muhammadiyah 1 Metro adalah senyum, sapa dan salam. Setiap peserta didik bertemu dengan orang lain, baik orang yang dikenalnya maupun tidak, peserta didik selalu membiasakan untuk bersikap ramah, senyum dan menggucapkan salam kepada setiap orang yang ditemuinnya. Siswa juga menunjukan etika yang baik jika bertemu dengan orang tidak meraka kenal. Ini terbukti ketika peneliti datang untuk pertama kalinya pada tanggal 19 Febuari 2019 disambut dengan ramah dan keterbukaan meskipun belum pernah bertemu atau mengenal satu sama lain.

Nilai kedisplinan yang ditunjukan oleh siswa dengan selalu membiasakan tepat waktu dalam melakukan segala hal, termasuk dalam mengikuti atau melakukan kegiatan nilai religious yang ditanamkan pada dirinya, seperti sholat dhuha, sholat berjama'ah dan lain sebagainya. Para peserta didik melakukannya dengan tertib dan disiplin. Hal ini juga disampaikan oleh Arif Rahman ${ }^{34}$ (siswa) mengatakan bahwa, sikap disiplin yang diterapan disekolah, berdampak positif, dan kita mulai terbiasa dengan sikap disiplin, seperti

34 Wawancara dengan Arif Rahman, Siswa Kelas XI IPA di SMA Muhammadiyah 1 Metro, 22-02-2019, pukul 10.00 WIB. disiplin waktu dan lain sebagainya. Berdasarkan hasil observasi dan wawancara yang telah dilakukan, maka dapat disimpulkan bahwa nilai akhlak dan kedisiplinan telah tertanam dengan baik. Dengan adanya pembiasaan dan nasihat yang diberikan terus menurus kepada peserata didik, maka tanpa disadari peserta didik dengan sendirinya akan melakukan hal-hal yang diajarkan atau yang ditanamkan pada diri peserta didik. Dengan demikian, maka dalam nilai akhlak dan kedisiplinan telah berjalan dengan baik dan berhasil sesuai dengan harapan dan tujuan sekolah.

3) Nilai Amanah dan Ikhlas

Nilai amanah atau dalam konsep kepemimpinan menurut Faturrahman dalam kosep kepemimpinan, amanah disebut juga dengan tanggung jawab. Dalam konteks pendidikan, nilai amanah harus dipegang oleh seluruh pengelola lembaga pendidikan. Sedangkan ikhlas diartikan bersih dari campuran dari hal kotor, secara umum ikhlas ialah hilangnya rasa pamrih atas segala sesuata yang dilakukannya. Dengan ditunjukannya nilai amanah dalam penanaman nilai-nilai religious, maka peserta didik akan lebih sadar tentang pengertian nilai amanah. Oleh Karenanya nilai amanah disini adalah kewajiban atau tugas sebagai peserta didik yang diamanahi kepadanaya. Yang harus di pertanggungjawabkan kepada Allah SWT, tidak hanya tanggung jawab pada diri sendiri dan juga tanggung jawab terhadap perbuatan yang dilakukannya.

Nilai ikhlas ditunjukkan dengan melaksanakan semua kegiatan keagamaan tanpa adanya paksaan. 
semua kegiatan dilakukan dengan senang hati dan ikhlas menjalaninya. Hal ini sesuai dengan hasil wawancara bersama Nurma Maisa Rahma (siswi), mengatakan bahwa Kegiatan yang diadakan oleh sekolah pasti bersifat baik dan membangun diri para siswa, jadi harus diikuti dengan penuh tanggung jawab dan keikhlasa. Menurut Esti Ernawati (siswi), juga menambahkan, bahwa nilai ikhlas harus dimiliki oleh setiap orang agar dalam melakukan suatu perkerjaan atau kegiatan apapun kalau itu baik maka ia kan mendapatkan pahala dari Allah SWT.

Berdasarkan hasil wawancara
yang telah dilakukan, bahwa penanaman nilai-nilai religious dengan mengadopsi pendidikan pesantren yang diterapkan disekolah mencakup nilai amanah dan nilai ikhlas yang berjalan dengan baik, dibuktikan dengan para peserta didik yang bertanggung jawab dengan kewajibannya dan tugasnya sebagai seorang muslim dan mengikuti kegiatan keagamaan tanpa perlu adanya keterpaksaan dan menjalankannya dengan keikhlasan.

4) Nilai Ruhul Jihad

Berdasarkan hasil observasi yang telah dilakukan, bahwa nilai Ruhul Jihad berperan sebagai pembangkit (motivasi) diri, untuk mendorong dalam melaksanakan semua kegiatan keagaman dalam penanaman nilai religius yang dilakukan oleh sekolah dan hasilnya kegiatan keagamaan yang diadopsi dari pesantren telah dicapai dengan baik, dibuktikannya dengan sikap pada diri peserta didik dalam melaksanakan kegiatan keIslaman dan membuat suasana sekolah seperti didalam pesantren, karena para pesarta didik menumbuhkan nilai dan budaya yang ada di pesantren. Bersadasarkan wawancara bersama Arif Rahman (siswa), mengatakan bahwa semua kegiatan yang bersifat positif wajib diikuti dengan baik dan sungguhsungguh demi kebaikan kami semua, agar bisa menjadi anak yang baik dan menjadi kebanggaan orang tua.

Kegiatan dalam penanaman nilainilai religious di sekolah SMA Muhammadiyah 1 Metro dilaksanakan menyeluruh dan berjalan dengan baik, diikuti dengan antusia para peserta didik. Berdasarkan hasil penelitian yang telah dilakukan, bahwa hasil penanaman nilai-nilai religious pada peserta didik terlihat melalui perkembangannya setiap individu dalam hal nilai keagamaan dan karakter religius yang dimiliki para peserta didik. Untuk menanamkan nilai-nilai religious, para peserta didik perlu adanya pendamping untuk mengembangkan dirinya dalam menghayati nilai religious tersebut.

\section{Faktor Pendorong dan Penghambat dalam Penanaman Nilai-nilai Religius Pada Peserta Didik}

Dalam sebuah proses yang berlangsung tidak bisa dipungkiri lagi bahwa masalah, kendala, keuntungan, kelebihan dan lain sebagainya menjadi suatu hal yang wajar terjadi. Ini menandakan bahwa proses yang ada benar-benar terjadi dan terlaksana sesuai dengan apa yang dirumuskan sejak awal. Dalam hal ini sesuai 
dengan pendapat Thoules Rebert ${ }^{35}$, sebagai berikut:

a. Faktor Penghambat dalam penanaman nilai-nilai religius

1) Kurang dan rendahnya kesadaran para peserta didik

Rendahnya kesadaran peserta didik terhadap pentingnya nilai-nilai religious, seperti saat akan melaksanakan kegitan pagi hari seperti membaca dan menyetorkan hafal al Qur'an kepada guru pembimbing, melaksanakan sholat dhuha berjamaah, masih ada siswa yang menggunakan cara paksaan atau di oprak-oprak oleh guru untuk segera pergi kemesjid dan melaksanakan sholat dan khususnya siswa yang perempuan ada beberapa yang beralasan berhalangan atau haid, entah itu benar atau tidaknya.

2) Kesulitan guru dalam pemantauan dan pengawasan siswa

Karakteristik siswa yang berbeda-beda menjadikan kesulitan guru dalam hal memantau sikap atau perbuatan anak didiknya. Hal ini akan terlihat ketika kegiatan keagamaan, misalnya tadarus Qur'an, sholat dhuha dan lainnya. Disekolah mana pun pasti juga mengalami masalah umum seperti ini, karena jumlah siswan yang lebih banyak, dan mempunyai karakteristik yang berbeda-beda sehingga jelas tidak mungkin guru dapat memantau seluruh siswa.

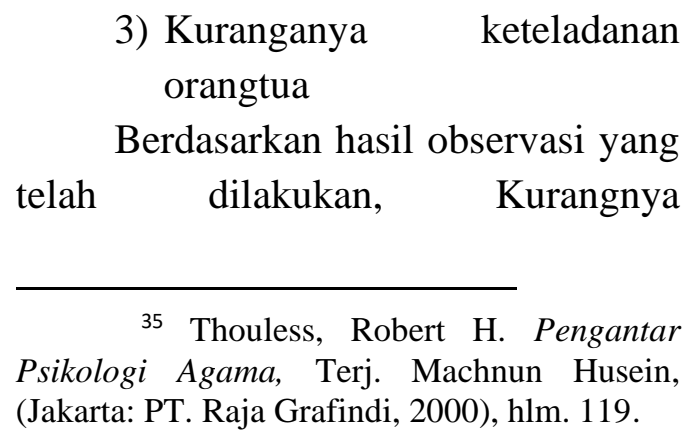

3) Kuranganya keteladanan Berdasarkan hasil observasi yang 195 keteladanan orangtua dirumah akan nampak ketika anak bertingkah laku kurang baik, dan tidak mengikuti kegiatan-kegiatan keagamaan disekolah Keluarga merupakan awal anak mendapatkan pendidikan, oleh karena itu betapa pentingnya peran keluarga (orangtua) dalam membentuk karakter anak. Penanaman nilai-nilai religius yang dilakukan disekolah dalam membentuk karakter religius siswa tanpa adanya peran aktif serta dukungan dari orang tua juga tak akan memperoleh hasil yang maksimal. Sebab waktu siswa di sekolah lebih sedikit dari pada waktu siswa di rumah. Oleh karena itu peran orangtua juga dibutuhkan dalam proses penanaman nilai religius yang telah ditanamkan disekolah.

4) Faktor lingkungan masyarakat Lingkungan masyarakat mempunyai pengaruh sangat besar dalam membentuk dan menentukan perubahan sikap anak. Dari pergaulan orangtuanya dan teman-temannya inilah yang akan mempengaruhi bagaimana anak akan berperilaku. Anak akan dapat mengetahui peristiwa dan pengalaman yang terjadi dimasyarakat. Oleh karena itu, dalam pergaulan dapat mempengaruhi pola pikir, sifat dan tingkah laku.

b. Faktor pendukung dalam penanaman nilai-nilai religius

Kegiatan harian yang dilakukan oleh peserta didik merupakan kegiatan rutin yang didalamnya ditanamkan nilai-nilai religius. kegiatan harian yang dilakukan ini merupakan salah satu kekuatan yang dimiliki dalam menanamkan nilai religius pada peserta didik agar dapat memiliki karakter 
yang religius. Dengan adanya kegiatan yang berdasarkan nilai pesantren yang diadopsi, maka peserta didik akan terbiasa untuk menjalankan, memprakatekkan dan merealisasikan dalam kehidupan sehari-hari. Dengan demikian nilai-nilai yang ada akan dapat diinternalisasikan dalam sebuah tindakan nyata dalam kehidupan sehari-hari.

Berdasarkan hasil observasi yang dilakukan, bahwasannya Faktor pendukung dalam penanaman nilainilai religius pada peserta didik tidak hanya dengan cara internalisasi yang dilakukan oleh warga sekolah saja, tetapi didukung juga dengan peraturan atau tata tertib yang dibuat untuk membiasakan peserta didik disiplin dan amanah atas tugasnya dan peraturan yang tidak boleh dilanggar. ${ }^{36}$ Dalam mendukung penanaman nilai-nilai religious adanya peran penting warga sekolah yang menciptakan suasana lingkungan religius dan dibuatnya tata tertib sekolah, dan kegiatan tambahan dari sekolah sehingga siswa akan terbiasa untuk melaksanakannya dalam kehidupan sehari-hari.

\section{KESIMPULAN}

Berdasarkan Dari hasil penelitian yang telah dilaksanakan bahwa dalam implementasi penanaman nilai-nilai religius pada peserta didik di SMA Muhammadiyah 01 Metro juga menyediakan asrama (boarding school) untuk menunjang proses penanaman nilai religius pada peserta didik. Dalam proses penanaman nilai religius SMA Muhammadiyah 1

36 Hasil Observasi di SMA Muhammadiyah 1 Metro, Rabu 6 Maret 2019
Metro sebagian besar mengadopsi pendidikan pesantrean, seperti kegiatan tadarus Qur'an, hafalan Qur'an, berdoa bersama, sholat dhuha, sholat berjam'ah, mendengarkan tausyiah. Karena diyakini pendidikan dan nilai pesantren dapat menghasilan peserta didik yang berkuliatas, memiliki karakter religius, disiplin, mandiri, tanggung jawab dan solidaritas yang tinggi.

Dalam implementasi penanaman nilai-nilai religius pada pesarta didik, SMA Muhammadiyah 1 Metro mengunakan startegi internalisasi, hal ini dapat memberikan penghayatan terhadap suatu nilai, sehingga merupakan keyakinan dan kesadaran akan kebenaran nilai yang ditanamkan pada diri setiap peserta didik. Berdasarkan penelitian yang telah dilaksanakan, diketahui SMA Muhammadiyah 1 Metro juga menggunakan metode untuk menunjang proses penanaman nilai-nili religius pada peserta didik, metode yang digunakan ialah metode pembiasaan, nasihat, keteladanan dan hukuman. Metode disini memegang peranan yang cukup penting dalam penanaman nilai religius pada peserta didik. Oleh karena itu, dengan adanya strategi dan metode dapat mempermudah proses pelaksanaan penanaman nilai-nilai religius dan menghasilkan peserta didik yang berkarater religius.

Berdasarkan hasil penelitian, dalam penanaman nilai-nilai religius pada peserta didik dengan mengadopsi pendidikan pesantren menuai keberhasilan, dapat berjalan dengan baik dan maksimal sesuai dengan yang 
direncanakan pihak sekolah. Nilai pesantren yang diadopsi, seperti nilai ibadah, nilai akhlak dan disiplin, nilai amanah dan ikhlas, dan nilai ruhul jihad. Keberhasil penanaman nilai-nilai religius pada peserta didik dapat terlihat dari perkembangan setiap individu. Perubah yang terjadi pada diri peserta didik ialah mempunyai kesadaran diri untuk melaksanakan kewajibannya sebagai seorang muslim.

Kegiatan keagamaan yang mengadopsi dari pesantren seperti sholat wajib berjama'ah, sholat jum'at berjama'ah, sholat dhuha, puasa sunnah, mengkaji al'Qur'an dan hadist dan sebagainya. Dalam proses ini, guru pengelola mencontohkan sebagai bentuk keteladanan pada peserta didik agar dapat mengikuti dan melakukan yang telah dicontohkan. Dalam penanaman nilai religius SMA Muhammadiyah membiasakan peserta didiknya untuk berinfaq tidak hanya dilakukan pada hari jum'at saja melainkan setiap hari, karena hasil infaq tersebut akan digunakan untuk bakti social atau membantu orang yang membutuhkannya. Peserta didik juga dibiasakan untuk melakukan kegiatan keagamaan seperti, tadarus Qur'an dan hafalan Qur'an, doa bersama sebelum dimulainya pelajaran, sholat dhuha dan mendengarkan tausiyah ba'da dzuhur. Selain itu kegiatan tersebut dapat menumbuhkan rasa disiplin dan tanggung jawab pada diri peserta didik, dalam melakukan kewajiban dan tugasnya sebagai seorang yang beragama dan pelajar.

Hasil penanaman nilai-nilai religius yang di terapkan dapat membuat suasana lingkungan sekolah menjadi religius, dengan membudayakan 3S (senyum, sapa dan salam), saling menghormati satu sama lain, bertanggung jawab, mandiri, disiplin dan toleransi. Oleh karena itu, kegitan keagamaan dalam penanaman nilai-nilai religius yang diterapkan di SMA Muhammadiyah 1 Metro berorientasi kepada kehidupan dunia dan akhirat. Penanaman nilai-nilai religius pada peserta didik menuai keberhasilan yang baik dan berjalan sesuai dengan harapan.

1. Faktor penghambat dan pendukung Faktor yang mempengaruhi penanaman nilai-nilai religius pada peserta didik di pengaruhi oleh factor yang bersifat eksternal dan internal. Jika dilihat secara rinci factor penghambat dalam penanaman nilai religius pada peserta didik, yaitu: 1) factor lingkungan masyarakat. 2). Pergaulan dengan teman sebaya. 3). Kurangnya peran orangtua. 4). Rendahnya kesadaran diri peserta terhadap kewajibannya.

Faktor pedukung dalam penanaman nilai-nilai religius pada peserta didik di SMA Muhammadiyah 1 Metro, sebagai berikut: 1). Sekolah menerapkan kegiatan-kegiatan keagaman yang diadopsi dari nilai-nilai pesantren, yang harus dilakukan oleh peserta didik. 2). Sekolah membuat peraturan atau tata tertib agar siswa menaati dan tidak melanggar apa yang sudah ditentukan, hal ini dapat mendukung dalam penaman nilai-nilai religius pada peserta didik. 


\section{DAFTAR PUSTAKA}

Abd, Halim Soebahar, Kebijakan Pendidikan Islam dari Ordonansi Guru sampai UU Sisdiknas, Jakarta: PT RajaGrafindo Persada, 2013.

Abu Yasid, Paradigma Pesantren, Meuju Pendidikan Islam Transformatif, Yogyakarta: IRCiSoD, 2018

Abdul Majid, Strategi Pembelajaran, Bandung: PT. Remaja Rosdakarya, 2013.

Abu Ahmad dan Noor Salim, DasarDasar Pendidikan Agama Islam, Jakarta: Bumi Aksara, 2008.

Ahmad Tafsir, Ilmu Pendidikan Islam,

Bandung: Remaja Rosdakrya, 2004.

Abuddin Nata, Pemikiran Pendidikan Islam \& Barat, Jakarta: PT RajaGrafindo Persada, 2013.

Alwi, Hasan dkk, Kamus Besar Bahasa

Indonesia, Jakarta: Pusat Bahasa Departemen Pendidikan Nasional dan Balai Pustaka, 2005.

Asmaun Sahlan, Mewujidkan Budaya Religius di Sekolah: Upaya Mengembangkan PAI dan Teori ke Aksi, Malang: UIN Press, 2010.

Charles Y. Glock and Rodney Stark, Religion and Society in Tension, Chicago: Rand McNally and Company, 1965

Doanea, M. J. The Associantion Between Religiosty and Subjective Well-Being: The Unique contribution of religious service attendance and the mediating role of perceived religious social support. The iris Jourbal of Psyhology, 43 (1), 2013

Faturrohman, Budaya Religius Dalam Peningkatan Mutu Pendidikan, Tinjauan Teoritik dan Praktik Konstekstualisasi Pendidikan Agama Di Sekolah, Yogyakarta: Kalimemedia, 2015.

Imam Bawai, Pengantar Ilmu Jiwa Perkembangan, Surabaya: PT. Bina Ilmu, 1985.

Maragustam, Filsafat Pendidikan Islam Menuju Pembentukan Karakter, Yogyakarta: Pascasarjana FITK UIN Sunan Kalijaga, 2018.

Pusat Bahasa Departemen Pendidikan Nasional, Kamus Besar Bahasa Indonesia, Jakarta: Balai Pustaka, 2003.

S. Nasution, Metode Research, (Peneltian Ilmiah), Jakarta: Bumi Aksara, Cetak ke-1, 1996.

Sugiyono, Metode Penelitian Pendidikan, Pendekatan Kuantitatif, Kualitatif dan $R \&$ $D$, Bandung: Alfabeta, 2011.

Thouless, Robert H. Pengantar Psikologi Agama, Terj. Machnun Husein, Jakarta: PT. Raja Grafindo, 2000.

Uhar Suharsaputra, Metode Penelitian Kualitatif, Kuantitatif dan Tindakan, Bandung: PT. Refika Aditama, 2012. 